\title{
A linguistic Analysis of the Primary Persuasive Strategies in Facebook Profile of AIG
}

Abdulrahman Sabah Ghane (M.A. Student)

Email: godsslave23@yahoo.com)

Asst. Prof. Huda Abed Ali Hattab (Supervisor)

University of Baghdad / College of Education - Ibn Rushud / Department of English

Received:4/8/2019

Accepted:21/12/2019

This work is licensed under a Creative Commons Attribution 4.0 International License

\begin{abstract}
The insurance company (or the insurer) like many other commercial organizations, needs persuasion for the sake of convincing the customers to buy his insurance products. The insurer uses many persuasive strategies through many platforms to persuade people to market his products.

The current study aims to analyze the primary persuasive strategies that are used by AIG in facebook profile in order to specify the most effective strategies used by the American insurers, and to suggest the most suitable strategies to the Iraqi insurers. The present study hypothesizes that the persuaders use more than one strategy together to achieve their goals, and the American insurers focus on the persuasive strategies that show the insurance significance.

This study analyzes nine samples by using the model suggested by Sabah (2019). It results in: the strategies are classified into three main types: primary, secondary and tertiary strategies and the ladder of the primary strategies suggested to Iraqi insurers (where there is no insurance awareness) is power, highlight benefits, context, character and emotions based on that of the American insurers: character, emotions, context, highlight benefits and power (where people have awareness of insurance).
\end{abstract}

Key words: persuasion, insurance, persuasive strategies and social media. 


\section{تحليل لغوي لاستر اتيجيات الإقتاع الرئيسية في صفحة$$
\text { شركة AIG على فيسبوك }
$$$$
\text { عبد الرحمن صباح غني }
$$ \\ godsslave23@yahoo.com \\ الأستاذ المساعد هدى عبد علي حطاب

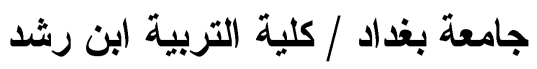

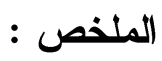

تحتاج شركة الثأمين (أو المؤمن) منل العديد من المؤسسات التجارية الأخرى ، إلى الإقتاع

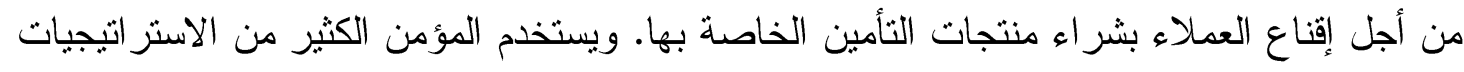
المقنعة بوساطة مختلف العديد من المنصات لإقناع الناس وتسويق منتجاته.

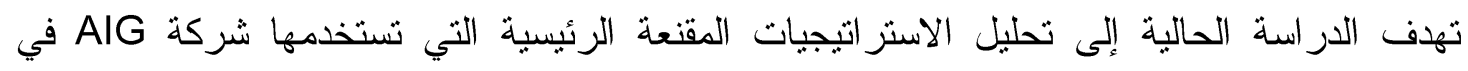

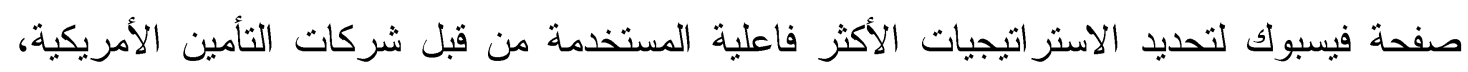

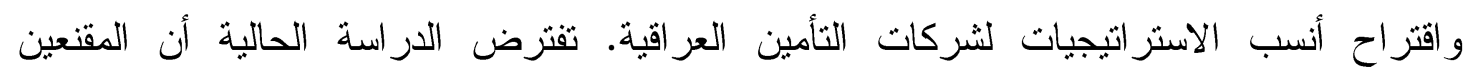

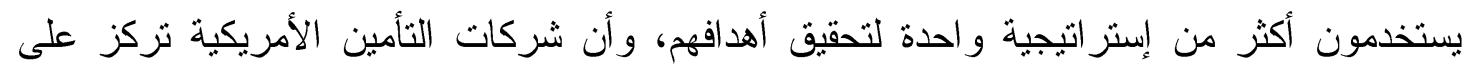
الإستر اتيجيات المقنعة التي تُظهر أهمية التأمين.

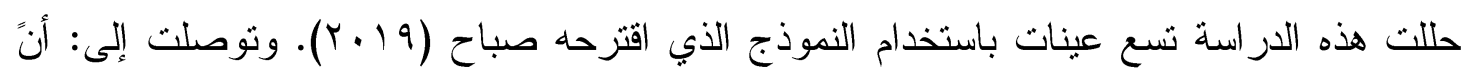

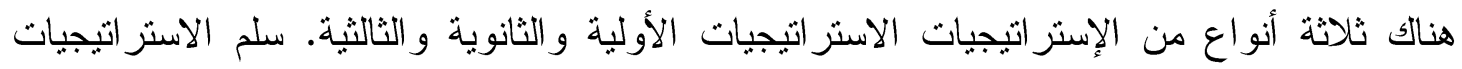

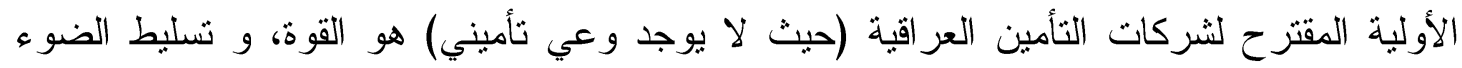

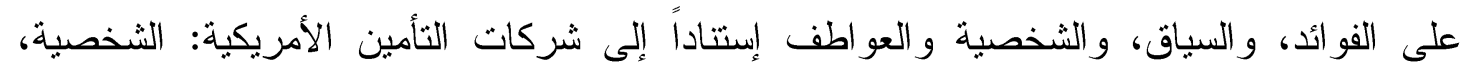

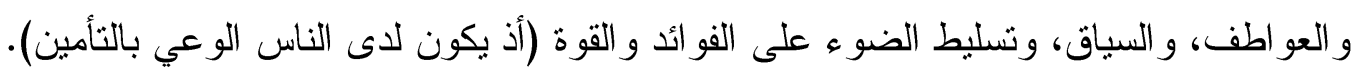

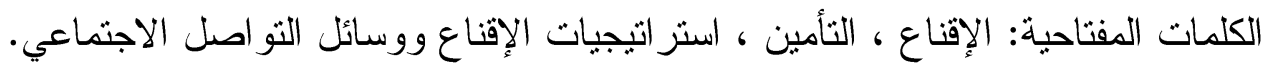




\section{SECTION ONE \\ PERSUASION AND PERSUASIVE STRATEGIES}

\subsection{Definition of Persuasion}

Many linguists define the act of persuasion in a rather similar way. Hereunder are some of them:

Cacioppo (1981:4 as cited in Muthana, 2015:55) states that persuasion is "any instance in which an active attempt is made to change a person's mind. $\square$ Lakoff (1982:57 as cited in Othman, 2015:1) defines the act of persuasion as the "attempt or intention of one party to change the behavior, feelings, intentions, or viewpoint of another by communicative means.

Adil (2016: 10) defines Persuasion as "a human communication that occurs intentionally to change people's attitudes. $\square$ On the other hand, Mohammed (2015)defines Persuasion as the process of creating, modifying or changing people's beliefs, values and attitudes.

According to the definitions above one can define persuasion as an intentional and conscious attempt by the persuader for a certain goal or purpose. The persuader strives to achieve his goal by using a persuasive language to change the beliefs, attitudes and values of the persuadee. However, the persuader may succeed in his mission and change the persuadee's behaviour, or he may fail even if he uses persuasive language.

\subsection{The Role of Persuasive Strategies in Persuasion}

According to the illustration above, one can notice the important role of communication and interaction in persuasion. The persuader cannot send his message and achieve his goal without communication or interaction with the persuadee and the best way for communication is the human language. In this respect, Lakoff (1982:57 as cited in Othman, 2015:1) states that persuasion is an attempt to change human's behavior through "communicative means.

One can find persuasion in many figures, e.g. political discourse, religious discourse, propaganda and advertisement, posts of social media, etc. (Othman, 2015). However, it is clear that some people can attract the attention of the audience while others are not. In other words, one person can inspire and persuade his audience; another sends them to sleep. When a successful orator speaks, people do not notice time passing, but when unsuccessful orator speaks, audience keep looking at their watch (Thompson, 1998 as cited in Mahmood, 2015).

The difference between successful orator (or persuasive language) and unsuccessful orator (or unpersuasive language) is the use of persuasive strategies. Those strategies are added to human language to make it more persuasive and effective and enable the persuader to achieve his goals. Aristotle calls the persuasive language as 'language of persuasion' (ibid). The figure below explains the language of persuasion:
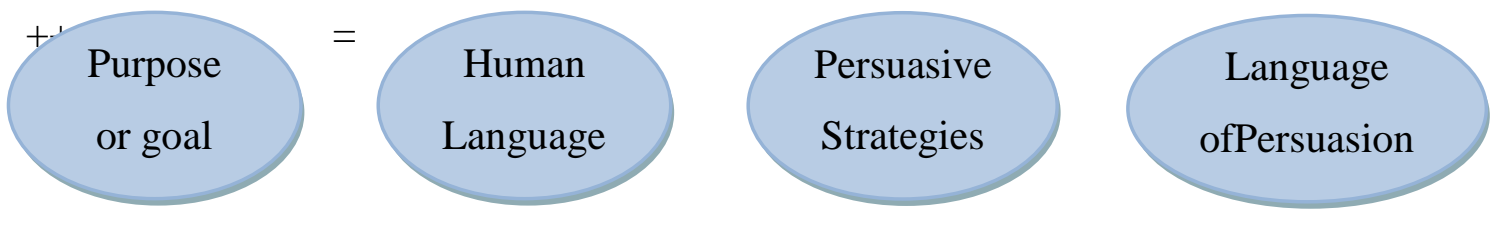

Figure No. (1)Language of Persuasion 


\subsection{Persuasive Strategies}

Sabah (2019) classifies the persuasive strategies into three main classes, as follows:

- Primary Strategies:the strategies that express the purpose of the text or speech. These strategies represent the base to which the others are attached. They include character, emotions, context, power and benefits.

- Secondary Strategies: the strategies that are usually used to confirm, emphasize or attract attention to the purpose of the primary strategies, and also sometimes used alone just as primary strategies. They include logic and draw attention.

- Tertiary Strategies: the strategies that are used as a framework in which the primary and secondary strategies are presented. They include arrangement and style.

This study will focus on primary strategies and their use.

\subsubsection{Primary Strategies}

\subsubsection{Context}

The persuader should take into consideration the context of communication including many factors such as time, place, objects, etc. The context enables the recipeint to link the persuader's message to the surrounding circumstances and make it more applicable. The persuader can also make use the shared knowledge between him and the recipient which leads to a better communication (Mulholland, 1994).

\subsubsection{Character}

The persuader can affect on his audience by focusing on his character (Perloff, 2003 as cited in Muthana, 2015). Character includes many factors such as: competence, honesty, politeness (Lucas, 2009) and celebrity (O'Shaughnessy\&O'Shaughnessy, 2004)

\subsection{Competence}

It refers to adequacy, efficiency, experience of a person (Lucas, 2009). The persuader should show the audience his competence and knowledge in the subject he discusses. For example:

- Before I studied antibacterial products in my public health class, I always used antibacterial soap and antibacterial all-surface cleaner for my apartment. I also know from my class ..., etc. (ibid:355).

\subsection{Honesty}

It refers to the person's safety and faithfulness. People trust and believe in the person who is faithful and fair and has good reputation. Consequently, the persuader needs to be honest in order to to gain people's trust (Perloff, 2003 as cited in Muthana, 2015).

\subsection{Politeness}

The strategies of politeness theory suggested by Brown and Levinson (1987) are the best devices for this purpose. They include solidarity and deference strategies. They are designed to deal with the two opposite wants of the recipients' faces (Mulholland, 1994).

\subsection{Solidarity Strategy}

It is the suitable strategy to deal with positive face. It is defined as the tendency to use positive politeness forms to emphasize the common ground, closeness and friendship between the speaker and hearer such as "personal information, nick names, sometimes even abusive terms (particularly among males), and shared dialect or slang 
expressions. $\square$ This strategy is used between people from the same level such as friends, employees, students ..., etc. (Yule, 1996:65).

Brown and Levinson (1987) determine three objectives for the goal of this strategy:

a- Create common ground: the speaker shows the hearer that they are close and belong to the same category or group, and have similar values and goals. This objective can be reached by following the sub-strategies below:

1- Show interest and attention to what the other says: the speaker should pay attention and show interest to the second speaker's speech. He should listen to the second speaker as he wants the second speaker to listen to him (ibid). The persuader should be a good listener as well as a good speaker.

2- Notice and attend the hearer's needs, wants and interests: the speaker notices and takes care of the hearer's condition such as "noticeable changes, remarkable possessions, anything which looks as though the hearer would want the speaker to notice and approve of it $\square$ (ibid:103). For example:

- Let me have those parcels, they look heavy (...) Remember we want a report by 5 P.M. today (Mulholland, 1994:230).

- You must be tired; here, sit down (...) Your reports are due (ibid).

The speakers, in the three examples above, notice and take care of want (in the $1^{\text {st }}$ example) and need (in the $2^{\text {nd }}$ example) before express their real intention (ibid).

b- Show cooperation:the speaker shows the hearer that they are cooperators and involved in the same activity. Consequently, they have the same goals and attitudes. In other words, if the persuader convinced the persuadee that they are cooperators, the persuadee would follow him and do like him (ibid).

This objective can be reached by following the sub-strategies below:

1- Confirm the speaker's knowledge of the hearer's want: the speaker shows the hearer that he knows and recognizes his wants (ibid). For example:

- Look, I know you want the car back by 5 O'clock, so shouldn't I go to town now? (ibid:125)

- I know you want to go to the cinema this week, so I will book tickets for 'Curse of Chucky'. I'm sure you will like it (Mulholland,1994:255).

The speakers, in the examples above, start their sentences by asserting knowledge of the hear's want (want the car at specific time in the $1^{\text {st }}$ example, and going to the cinema in the $2^{\text {nd }}$ example) and then present their real purpose (going to the town in the $1^{\text {st }}$ example, and booking for a movie in the in the $2^{\text {nd }}$ example).

2- Offer or Promise: the speaker tries to show cooperation with the hearer by presenting offers or promises of whatever the hearer wants (Brown and Levinson, 1987). For example:

- I promise I'll give you whatever you like.

3- Reciprocity: this substrategy is based on the principle that people tend usually to help people who helped or will help them (Cialdini, 2009 as cited in Morris, 2018).

Accordingly, the persuader can offer to make a favour in return for another one (Mulholland, 1994). For example:

- I'll lend you my new bike on Sunday afternoon if you borrow me your car for an hour or so (ibid:256). 
The persuader can also remind the receipient of a favour he has already made for him. For example:

- Please help me with my homework as I helped you with yours the last week (ibid).

4- Be optimistic: the speaker assumes that the hearer is cooperative with him and will help him (Mulholland, 1994). For example:

- Look, I'm sure you won't mind if I borrow your typewriter (Brown and Levinson, 1987:126).

5- Involve the speaker and hearer in the activity: some words refer to the sense of cooperation such as the pronoun 'we' and the expression 'let's'. They include the speaker and hearer in the same action (Brown and Levinson,1987). For example:

- We will shut the door, ma'am. The wind's coming in (ibid:127).

- Come on, let's go to the party. It will be fun (Yule, 1996:66).

The words we (in the $1^{\text {st }}$ example) and let's (in the $2^{\text {nd }}$ example) involve both the speaker and hearer in the same activity and show that they are cooperators. Consequently, they have the same advantage (avoiding the wind by closing the door in the $1^{\text {st }}$ example, and having fun in the $2^{\text {nd }}$ example) (Brown and Levinson,1987).

6- Give (or ask for) reasons: the speaker can ask the hearer for something and give him a reason. The speaker by doing so tries to make the hearer cooperate with him (Mulholland, 1994). For example:

- Can I borrow your books because I have an assignment? (ibid)

c- Fulfill the hearer's wants: the speaker tries to achieve some wants for the hearer to reinforce the sense of friendship (ibid). There is only one substrategy to fulfill this objective.

1- Present gifts: the speaker present gifts to the hearer (such as on his birthday or at other occasions). However, the gifts are preferred to be not too much and not too big otherwise it can be considered as an attempt of bribe (Mulholland, 1994).

For example, some shops present free soft drink before their clients buy anything (Walton, 2007 as cited in Adil, 2016).

\subsection{Deference Strategy}

It is the suitable strategy to deal with negative face. It is defined as the tendency to use negative politeness forms to emphasize the hearer's independece and freedom such as formality, impersonality and apology for the imposition. This strategy is used between people from different levels such as employee - employer, student - teacher ..., etc. (Yule, 1996).

It is important to note that solidarity is preferred over deference strategy, especially when the persuader directs his message to a group of people. For example, the writer to the readers, or the speaker to his audience in public speech (Perloff, $2003 \&$ Campbell and Huxman, 2009 as cited in Muthana, 2015).

Solidarity strategy refers to the qualities of being friendly and cooperative. The persuader can convey these qualities by creating common ground, showing cooperation and fulfilling the others' wants.

The speaker, in the example below, tries to create a common ground by affirming group membership between him and his audience: 
As we all know, there are many differences among the people in the class. But regardless of major, age ,goals, or background, we all share one thing in common - we are all concerned with the quality of education at this school. And that quality is clearly in danger. Because of ..., etc. (Lucas, 2009:356).

\subsection{Celebrity}

Celebrities are individuals who are known by most people such as actors, singers, youtubers, footballers, etc. Most people trust celebrities and believe their speech. Therefore many commercial organizations resort to celebrities to market their products through them (O'Shaughnessy\&O'Shaughnessy, 2004).

It is important to note the persuader's character is not a moment born i.e. the persuader should not only be faithfull, friendly, etc. only when he wants to persuade someone, these qualities should be attributed to him all the time (Boone and Kurtz, 1994 as cited in Muthana, 2015).

\subsubsection{Emotions}

The persuader can affect on his audience and persuade them by moving their emotions or passions (Thompson, 1998 \& Baeker, 2010 as cited in Mahmood, 2015). Emotions are able to change the human's mind (Boone and Kurtz, 1994 as cited in Adil, 2016). This strategy, then, is directed to the recipient's heart (Thompson, 1998 as cited in Mahmood, 2015).

There are many emotions that can be used by the persuader such as anger, calmness, intimacy, compassion, love, fear, disappointment, surprise ..., etc. (Aristotle, 2007 as cited in Mahmood, 2015). Those emotions are used to make the audience feel angry, quiet, compassionate, afraid, excited ..., etc. (Lucas, 2009 as cited in Mahmood, 2015). Hereunder are some of the emotions often used:

\subsection{Fear}

Fear is defined as a kind of worry or tension which is derived from a possible destruction or problem, especially if it is near (Aristotle, 2007).

For instance, the persuader can warn people in order to make them feel afraid. The fear emotion is very effective device because it makes people be away from the fear source (Leventhal, 1970 as cited in Mahmood, 2001). For example:

- $\quad$ Smoking is the main cause for lungs cancer.

The example above is considered as a caution which makes the reader feel afraid and consequently be away from smoking.

\subsection{Confidence}

Confidence is to feel certain and trust in something or somebody because it is reliable and powerful, or when sources of aid are provided (Aristotle, 2007).

\subsection{Friendliness}

It is the feeling that results from gently treatment, assistance and cooperation (ibid). It is fair to say that the friendly character (explained earlier) can create this feeling.

\subsubsection{Power}

It is possible to make someone forced or obliged to do something by using the speaker's authority (obligation), the laws and regulations (necessity) or other circumstances (need).

\subsection{Obligation}

It is to express something personal reflecting the speaker's opinion (Tammekänd, 2009). In other words, it expresses something internal to the speaker (Lane, 2019). It usually shows the speaker's authority (Palmer, 1990 as cited in Ahmed, 2009). The 
following modal auxiliaries and marginal modal auxiliaries are usually used to express obligation (must, have to, need / need to, should and ought to)

Obligation can also be expressed without using modals, e.g.

- Don't do that (Mulholland, 1994:114).

- I do not want to see you doing that again (Mulholland, 1994:114).

\subsection{Necessity}

It is to express something impersonal, usually stating laws and regulations (Tammekänd, 2009). In other words, it expresses something external to the speaker (Lane, 2019). The speaker usually is not in a position of authority (Palmer, 1990 as cited in Ahmed, 2009). The following modal and marginal modal auxiliaries are usually used to express necessity (have to, must, need / need to, should and ought to) Necessity can also be expressed without using modals, e.g.

- Members are forbidden to use the library after 9 P.M. (Mulholland, 1994:114)

- Parking here is not allowed (ibid).

\subsection{Need}

It is a special kind of necessity. The speaker, like necessity, is not in a position of authority. Need is different from necessity in that it does not refer to laws and regulations. It instead refers to something related to forced circumstances or reasons (van der Auwera\&Plungian, 1998as cited in Ahmed, 2009). The following verbs are often used to express need (need, need to and must)

Need can also be expressed without using modals, e.g.

- Water is essential for the survival of life, water is useful to people in many other ways. This is proved by the fact that most ancient civilizations grew along the banks of rivers or in areas with plenty of water. People use water for domestic activities such as cooking, bathing and washing. (Krishna, 2006:3).

The speaker, in the example above, gives the reasons why people need water and cannot live without it.

\subsubsection{Highlight Benefits}

The persuader can reach his goal by showing the advantages, privileges and positive sides of something (Tasso, 2018). In the same context, Harvard (2005:80) states that "by spotlighting the unique advantages of your proposition, you will convince listeners that your idea merits serious consideration. $\square$ For example:

- Samsung Galaxy Note 9 has unique merits that meet the consumer's needs; it has long battery life,big storage capacity and high resolution camera (Swider, 2019).

Instead of: Samsung presents its new model of Galaxy Note 9.

\section{SECTION TWO \\ METHODOLOGY \& DATA ANALYSIS}

\subsection{Methodology}

\subsubsection{The Proposed Model}

The model of Sabah (2019) is going to be used for analysis which is explained in section one, as shown in the figure below:

\section{Persuasive Strategies}

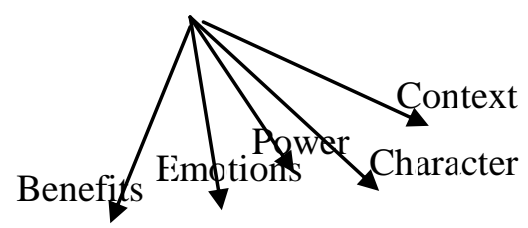




\subsubsection{The Chosen Samples}

Figure No.(2) Model of Analysis

The samples that will be analyzed are nine, taken from one of the largest insurance companies in USA. AIG: instituted in 1919, AIG is a global insurance company providing protection to more than 80 countries and jurisdictions and marketing many types of insurance.

The nine samples constitute the last ten posts circulated on AIG's profile on Facebook, as on July 26, 2019.

\subsection{Data Analysis}

\begin{tabular}{|c|c|c|c|}
\hline $\begin{array}{l}\text { Sa } \\
\mathrm{mp} \\
\text { le } \\
\text { No }\end{array}$ & The Post & The Post Details & Analysis \\
\hline 1. & $\begin{array}{l}\text { "AIG's Tom } \\
\text { Leonardi } \\
\text { discusses why } \\
\text { using genetic } \\
\text { testing in the } \\
\text { life insurance } \\
\text { process allows } \\
\text { for better risk } \\
\text { assessment and } \\
\text { transparency } \\
\text { for } \\
\text { consumers. }\end{array}$ & $\begin{array}{l}\text { A post taken from AIG's } \\
\text { profile on facebook, } \\
\text { posted on June } 24,2019 . \\
\text { The post is about why } \\
\text { insurers use the genetic } \\
\text { testing in the life } \\
\text { insurance process. }\end{array}$ & $\begin{array}{l}\text { Highlight Benefits: the insurer } \\
\text { states how genetic testing has } \\
\text { important role in life insurance } \\
\text { process. }\end{array}$ \\
\hline 2. & $\begin{array}{l}\text { Our ERGs } \\
\text { invited } \\
\text { Congressman } \\
\text { Mark Takano } \\
\text { to speak about } \\
\text { the next step in } \\
\text { the fight for } \\
\text { equality. As } \\
\text { the first openly } \\
\text { gay person of } \\
\text { Asian descent } \\
\text { in Congress, } \\
\text { he shared his } \\
\text { inspiring story } \\
\text { of overcoming } \\
\text { prejudice and } \\
\text { why passage of } \\
\text { the Equality } \\
\text { Act is a } \\
\text { watershed }\end{array}$ & $\begin{array}{l}\text { A post taken from AIG's } \\
\text { profile on facebook, } \\
\text { posted on June } 26,2019 . \\
\text { The post is about AIG's } \\
\text { invitation to a known } \\
\text { character of the LGBTQ } \\
\text { community to talk about } \\
\text { their rights. }\end{array}$ & $\begin{array}{l}\text { 1-Character } \\
\text { a-Politeness } \\
\text { i- Solidarity: the insurer confirms } \\
\text { his solidarity to those who have a } \\
\text { special sexual orientation, } \\
\text { including lesbian, gay, bisexual, } \\
\text { transgender and queer (LGBTQ), } \\
\text { by inviting a common character of } \\
\text { this community to talk about their } \\
\text { rights. } \\
\text { 2-Emotions the insurer's } \\
\text { A-Friendliness: thith } \\
\text { solidarity with } \\
\text { community generates friendliness } \\
\text { emotion. } \\
\text { 3-Context: the insurer circulates } \\
\text { this post in June (the Pride Month, } \\
\text { a month which is celebrated every } \\
\text { year by the LGBTQ community). }\end{array}$ \\
\hline
\end{tabular}




\begin{tabular}{|c|c|c|c|}
\hline & $\begin{array}{l}\text { moment for the } \\
\text { LGBTQ } \\
\text { community. }\end{array}$ & & \\
\hline 3. & $\begin{array}{l}\text { "The freedom } \\
\text { to focus on } \\
\text { growing their } \\
\text { companies and } \\
\text { living } \\
\text { comfortably in } \\
\text { retirement. }\end{array}$ & $\begin{array}{l}\text { A post taken from AIG's } \\
\text { profile on facebook, } \\
\text { posted on June } 27,2019 \text {. } \\
\text { The post is about } \\
\text { insurance importance. }\end{array}$ & $\begin{array}{l}\text { Highlight Benefits:the insurer } \\
\text { showsthe benefits of insurance for } \\
\text { the companies and individuals. }\end{array}$ \\
\hline 4. & $\begin{array}{l}\text { "At last week's } \\
\text { Global } \\
\text { Insurance } \\
\text { Forum, AIG's } \\
\text { Brian } \\
\text { Duperreault, } \\
\text { Chris } \\
\text { Townsend } \\
\text { \&Sachin Shah } \\
\text { reflected on } \\
\text { transformation } \\
\text { s within the } \\
\text { industry and } \\
\text { how insurance } \\
\text { can help } \\
\text { protect people } \\
\text { globally. }\end{array}$ & $\begin{array}{l}\text { A post taken from AIG's } \\
\text { profile on facebook, } \\
\text { posted on July 1, } 2019 . \\
\text { The post is about AIG's } \\
\text { participation in Global } \\
\text { Insurance Forum and } \\
\text { how they show the } \\
\text { importance of insurance. }\end{array}$ & $\begin{array}{l}\text { 1-Character } \\
\text { a-Competence: this post shows } \\
\text { how the insurer participates in } \\
\text { important and global forums } \\
\text { discussing the insurance role in } \\
\text { protecting people. } \\
\text { 2-Emotions } \\
\text { a-Confidence: the insurer's } \\
\text { competence described above } \\
\text { creates confidence inside the } \\
\text { recipient towards him. } \\
\text { 3-Highlight Benefits: the insurer } \\
\text { shows the role of insurance to } \\
\text { protect people. }\end{array}$ \\
\hline 5. & $\begin{array}{l}\text { "Our } \\
\text { colleagues } \\
\text { around the } \\
\text { world } \\
\text { celebrated \#PR } \\
\text { IDEMonth this } \\
\text { June \& } \\
\text { marched for } \\
\text { the } \\
\text { advancement } \\
\text { of LGBTQ } \\
\text { rights! }\end{array}$ & $\begin{array}{l}\text { A post taken from AIG's } \\
\text { profile on facebook, } \\
\text { posted on July 1, 2019. } \\
\text { The post is about AIG's } \\
\text { celebration with LGBTQ } \\
\text { community in their } \\
\text { month. }\end{array}$ & $\begin{array}{l}\text { 1-Character } \\
\text { a-Politeness } \\
\text { i-Solidarity: the insurer confirms } \\
\text { his solidarity to those who have a } \\
\text { special sexual orientation, } \\
\text { including lesbian, gay, bisexual, } \\
\text { transgender and queer (LGBTQ), } \\
\text { by celebrating and marching for } \\
\text { the advancement of their rights. } \\
\text { 2-Emotions the insurer's } \\
\text { a-Friendliness: the } \\
\text { solidarity with } \\
\text { community generates friendliness } \\
\text { emotion. } \\
\text { 3-Context: the insurer circulates } \\
\text { this post after one day of June (the } \\
\text { Pride Month, a month which is } \\
\text { celebrated every year by the } \\
\text { LGBTQ community). }\end{array}$ \\
\hline
\end{tabular}




\begin{tabular}{|c|c|c|c|}
\hline 6. & $\begin{array}{l}\text { "AIG has long } \\
\text { supported } \\
\text { educational } \\
\text { programs that } \\
\text { prepare young } \\
\text { talent to } \\
\text { become our } \\
\text { future } \\
\text { leaders. }\end{array}$ & $\begin{array}{l}\text { A post taken from AIG's } \\
\text { profile on facebook, } \\
\text { posted on July } 11,2019 \text {. } \\
\text { The post is about AIG's } \\
\text { support to education. }\end{array}$ & $\begin{array}{l}\text { 1-Character } \\
\text { a-Politeness } \\
\text { i-Solidarity: the insurer shows his } \\
\text { solidarity to one of the most } \\
\text { important people's needs, } \\
\text { education. } \\
\text { 2-Emotions } \\
\text { a-Friendliness: the insurer's } \\
\text { support to the education generates } \\
\text { friendliness emotions. }\end{array}$ \\
\hline 7. & $\begin{array}{l}\text { "Visit our site } \\
\text { for steps to } \\
\text { take during } \\
\text { and after the } \\
\text { storm. For } \\
\text { claims } \\
\text { assistance, call } \\
877-244- \\
0304 . \underline{h t t p: / / s p r} \\
. \text { ly/6180EvdF } \\
\underline{\text { a }}\end{array}$ & $\begin{array}{l}\text { A post taken from AIG's } \\
\text { profile on facebook, } \\
\text { posted on July 12, } 2019 \text {. } \\
\text { The post invites people } \\
\text { to visit AIG's website for } \\
\text { steps to be taken before, } \\
\text { during and after the } \\
\text { storm, and also invite his } \\
\text { insureds to call the } \\
\text { insurer for claim } \\
\text { assistance. }\end{array}$ & $\begin{array}{l}\text { 1-Character } \\
\text { a-Politeness } \\
\text { i-Solidarity: the insurer shows his } \\
\text { solidarity by inviting people to } \\
\text { visit his website where they can } \\
\text { find a link for PDF. The PDF } \\
\text { includes tips and actions to be } \\
\text { taken before, during and after the } \\
\text { storm which help people keep } \\
\text { safe, and reduce the possible } \\
\text { damages. } \\
\text { The insurer also invites his } \\
\text { insureds to call for claim } \\
\text { assistance. } \\
\text { 2-Emotions } \\
\text { a-Friendliness: the insurer's } \\
\text { cooperation with people by } \\
\text { providing free instructions and } \\
\text { claim assistance to his clients } \\
\text { generates friendliness emotions. } \\
\text { 3-Context: the insurer circulates } \\
\text { this post in conjunction with } \\
\text { Tropical Storm Barry. This storm } \\
\text { or hurricane occurs in the state of } \\
\text { Louisiana on July, 2019. It lasts } \\
\text { about a month and leaves huge } \\
\text { damages ("Tropical Storm } \\
\text { Barry } \square \text {, 2019 \& "Hurricane } \\
\text { Barry } \square \text {, 2019). }\end{array}$ \\
\hline 8 & & $\begin{array}{l}\text { A post taken from AIG's } \\
\text { profile on facebook, } \\
\text { posted on July } 17,2019 . \\
\text { The post is about } \\
\text { NatáliaSaltoratto (one of } \\
\text { AIG's employees) who is } \\
\text { talent in a Rubik's Cube. }\end{array}$ & $\begin{array}{l}\text { 1-Character } \\
\text { a-Competence: two uses for this } \\
\text { factor can be recognized: } \\
\text { 1-The insurer shows his } \\
\text { competence by introducing a talent } \\
\text { employee (NatáliaSaltoratto), this } \\
\text { can be noticed from the 1st till the } \\
\text { 4th paragraph. }\end{array}$ \\
\hline
\end{tabular}




\begin{tabular}{|c|c|c|c|}
\hline & & & $\begin{array}{l}\text { 2-The insurer also shows his } \\
\text { competence in the 5th paragraph. } \\
\text { He indicates how their employees } \\
\text { are submitted to training programs } \\
\text { to develop them using } \\
\text { Natália'swords to support that. } \\
\text { 2-Emotions } \\
\text { a-Confidence: showing the } \\
\text { efficiency of the insurer's staff } \\
\text { gives the clients confidence in the } \\
\text { insurer. }\end{array}$ \\
\hline 9. & $\begin{array}{l}\text { "We're pleased } \\
\text { to announce } \\
\text { Karen Ling as } \\
\text { AIG's new } \\
\text { CHRO. } \\
\text { Starting next } \\
\text { week, she will } \\
\text { bring her deep } \\
\text { human } \\
\text { resources } \\
\text { expertise to } \\
\text { help AIG align } \\
\text { its } \\
\text { strategy with } \\
\text { the company's } \\
\text { long-term } \\
\text { objectives. } \\
\text { We're excited } \\
\text { to welcome her } \\
\text { to AIG! } \square\end{array}$ & $\begin{array}{l}\text { A post taken from AIG's } \\
\text { profile on facebook, } \\
\text { posted on July 22, } 2019 . \\
\text { The post is about the } \\
\text { AIG's new CHRO (Chief } \\
\text { human resources officer) } \\
\text { (Karen Ling). }\end{array}$ & $\begin{array}{l}\text { 1-Character } \\
\text { a-Competence: the insurer shows } \\
\text { his competence by introducing a } \\
\text { new talent CHRO (Karen Ling. } \\
\text { 2-Emotions } \\
\text { a-Confidence: showing the } \\
\text { efficiency of the insurer's staff } \\
\text { gives customers confidence in the } \\
\text { insurer. }\end{array}$ \\
\hline
\end{tabular}

\section{SECTION THREE \\ RESULTS AND DISCUSSION}

\subsection{Discussion of the Results}

The following table shows the results of the analysis of the strategies in the chosen samples:

\begin{tabular}{|c|c|c|c|c|c|c|c|c|c|c|}
\hline \multirow{2}{*}{$\begin{array}{l}\text { Sample } \\
\text { No. }\end{array}$} & \multicolumn{2}{|c|}{ Character } & \multicolumn{2}{|c|}{ Emotions } & \multicolumn{2}{|c|}{ Power } & \multicolumn{2}{|c|}{ Benefits } & \multicolumn{2}{|c|}{ Context } \\
\hline & Freq & Pct & Freq & Pct & Freq & Pct & Fq. & Pct & Freq & Pct \\
\hline 1 & 0 & 0 & 0 & 0 & 0 & 0 & 1 & 100 & 0 & 0 \\
\hline 2 & 1 & $\begin{array}{c}33 \\
3\end{array}$ & 1 & $\begin{array}{c}33 . \\
3\end{array}$ & 0 & 0 & 0 & 0 & 1 & $\begin{array}{c}33 . \\
3\end{array}$ \\
\hline 3 & 0 & 0 & 0 & 0 & 0 & 0 & 1 & 100 & 0 & 0 \\
\hline 4 & 1 & $\begin{array}{c}33 . \\
3\end{array}$ & 1 & $\begin{array}{c}33 . \\
3\end{array}$ & 0 & 0 & 1 & $\begin{array}{c}33 . \\
3\end{array}$ & 0 & 0 \\
\hline 5 & 1 & 33. & 1 & 33. & 0 & 0 & 0 & 0 & 1 & 33. \\
\hline
\end{tabular}




\begin{tabular}{|l|c|c|c|c|c|c|c|c|c|c|}
\hline & & 3 & & 3 & & & & & & 3 \\
\hline $\mathbf{6}$ & 1 & 50 & 1 & 50 & 0 & 0 & 0 & 0 & 0 & 0 \\
\hline $\mathbf{7}$ & 1 & 33. & 1 & 33. & 0 & 0 & 0 & 0 & 1 & 33. \\
& & 3 & & 3 & & & & & & 3 \\
\hline $\mathbf{8}$ & 2 & 50 & 2 & 50 & 0 & 0 & 0 & 0 & 0 & 0 \\
\hline $\mathbf{9}$ & 1 & 50 & 1 & 50 & 0 & 0 & 0 & 0 & 0 & 0 \\
\hline Total & 8 & $\mathbf{3 1}$ & 8 & $\mathbf{3 1}$ & 0 & $\mathbf{0}$ & 3 & $\mathbf{2 6}$ & 3 & $\mathbf{1 1}$ \\
\hline
\end{tabular}

Table No. (1) Use of the Primary Strategies in the Chosen Samples

The results of the table above show that character and emotions come first, followed by benefits and context. Each one will be explained in brief below:

\subsubsection{Character}

Although this strategy gets the same rate like emotions, it can be considered the first. That is because it leads to the emotions such as confidence and friendliness.

Character is considered a very important strategy especially in the countries where people have awareness of the insurance significance.

In USA, people know the important role of insurance therefore the American insurers do not give the priority to the strategies that urge people to buy insurance products. They instead focus on showing their character as well as addressing the clients' emotions. Such strategies support the insurer's position among the other competitors.

Accordingly, one can expect that the insurers, in other countries where people have no awareness of the insurance significance (like Iraq), focus more on the strategies that motivate people to buy insurance products.

\subsubsection{Emotions}

Emotions strategy records $31 \%$, like character, but it is considered the second (after character strategy) because many emotions are generated as a result of character's factors.

\subsubsection{Benefits}

The third place is occupied by highlight benefits strategy. The results show that $26 \%$ out of all primary strategies used by the insurers is highlighting benefits.

The American insurers do not give priority to this strategy. They do not focus a lot on persuading people to buy insurance products because people already have awareness of the insurance significance. That is why this strategy comes after character and emotions strategies

One can expect that the insurers in other countries, where people have no awareness of the insurance significance (like Iraq), focus more on highlighting insurance benefits to motivate people to buy insurance products.

\subsubsection{Context}

Context strategy occupies the fourth place. It records $11 \%$. It is important to take into consideration the context factors such as time, circumstances, place, etc. and employ them, as a persuasive strategy, in the persuader's message.

\subsubsection{Power}

The results show that power strategy percentage, out of all primary strategies used by the insurers, is $0 \%$. Like the benefits strategy, the American insurers do not need to show the necessity or the serious need of insurance because the American people already know that. 


\subsection{Primary Strategy Ladders}

According to the results of the analysis of both the chosen samples as well as the content of their links, the researcher proposes two types of primary strategy ladders. Ladder (A) is designed for the countries where people are aware of insurance significance, and ladder (B) is designed for the countries where people are not aware of insurance significance. As shown in the figure below:

Power

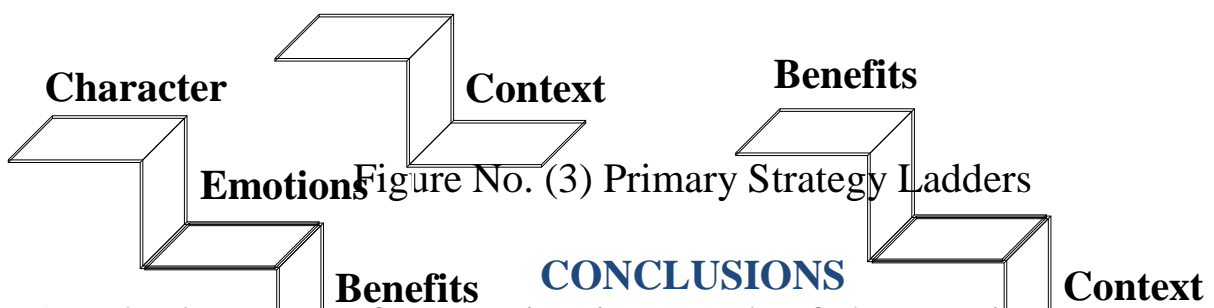

1- The language of persuasion is a result of three main eompenents: purpose, language and persuasive strategies.

2- Persuasive strategies are the strategies added to human language character make it more persuasive and effectitve. They help the persuader to achise his dais.

${ }^{3}$ Lathertyategies are classified inforke main typesidder (B)

a- Primary strategies: the strategizs that express the purpose of the speech. They include character, emotions, power, highlight benefits and context.

b- Secondary strategies: the strategies that are usually used to confirm, emphasize or attract attention to the purpose of the primary strategies, and also sometimes used alone just as primary strategies. They include logic and draw attention.

c- Tertiary strategies: the strategies that are used as a framework in which the primary and secondary strategies are presented. They include arrangement and style.

4- There is a relation between the primary persuasive strategies. One can lead to another. For example, fear (emotions) can lead to need (power), competence (character) can lead to confidence (emotions).

5- The ladder of the primary strategies for the countries where people are aware of insurance significance is character, emotions, highlight benefits, context and power. On the other hand, the ladder for the countries where people have no awareness of insurance is highlight benefits, power, context, character and emotions. 


\section{REFERENCES}

Adil, E. (2016). Persuasive Strategies in Tourism Language: A Pragmatic Study. Master Thesis. University of Baghdad, Iraq.

Ahmed, O. (2009). Modality in English and Arabic: A Contrastive Study. PhD. diss. University of Baghdad, Iraq.

Aristotle. (2007). On Rhetoric. Kennedy, G.A. (Trans.). New York: Oxford University Press.

Benoit, W. (n. d.). The Nature of Attitudes and Persuasion. Retrieved from http://www.cios.org/encyclopedia/persuasion/Aintroduction_1whatis.htm.

Brown, P. and Levinson, S. (1987). Politeness: Some Universals in Language Usage. New York: Cambridge University Press. Retrieved http://gen.lib.rus.ec/book/index.php?md5=7FA39DDEBDE3F887E1E3E1075FA24D69.

Harvard. (2005). Power, Influence, and Persuasion: Sell Your Ideas and Make Things Happen. USA: Harvard Business Press. Retrieved from https://books.google.iq/books?id=RZaaJH7fWJMC\&dq.

Krishna, N. (2006). Allied S Environmental Education for Class 7. India: Allied Publishers. Retrieved from https://books.google.iq/books?id=hGTwBGIdLtgC\&dq.

Lane, R. (2019). Expressing Obligation.Retrieved from https://www.hornerschool.com/expressingobligation/.

Lucas, S. (2009). The Art of Public Speaking (10 ${ }^{\text {th }}$ ed.). USA: McGraw-Hill. Retrieved from http://93.174.95.29/_ads/95BF4D5A4F923C1A9D1D7C5C690E2A7A.

Mahmood, M. (2001). A Pragmalinguistic Analysis of the Electoral Propaganda Used in English Political Texts. Master Thesis. University of Baghdad, Iraq.

Mahmood, S. (2015). A Linguistic Study of Persuasive Strategies In English Religious Sermons. Master Thesis. University of Baghdad, Iraq.

Modals.(2010). Retrieved from http://english-learners.com/2010/02/obligation-and-necessitymodals.html.

Mulholland, J. (1994). Handbook of Persuasive Tactics: A Practical Language Guide. London: Routledge. Retrieved from http://93.174.95.29/_ads/E2B00568FD2AC0C9907D766F63CC1B6B.

Muthana, L. (2015). Investigating the Role of Metadiscourse Markers in the Attainment of Persuasion in American Presidential Inaugural Speeches. PhD. diss. University of Baghdad, Iraq.

O'Shaughnessy, N., J. \& O'Shaughnessy, J. (2004). Persuasion in Advertising. UK: Routledge. Retrieved from https://books.google.iq/books?id=h4AfKMN6pRYC\&dq. 
Othman, I. (2015). A Pragmatic Study of Iraqi EFL Learners in Recognizing and Producing the Speech Act of Persuasion. Master Thesis. University of Baghdad, Iraq.

Sabah, A. (2019). A Linguistic Analysis of The Persuasive Strategies in the Social Media of Insurers. MA. Thesis. University of Baghdad, Iraq.

Swider, M. (2019).Samsung Galaxy Note 9 review.Retrieved from https://www.techradar.com/reviews/samsung-galaxy-note-9-review/6.

Tammekänd, L. (2009). Obligation and Necessity.Retrieved from http://modalsinnature.weebly.com/obligation-and-necessity.html.

Tasso, K. (2018). Better Business Relationships: Insights from Psychology and Management for Working in a Digital World. UK: Bloomsbury Publishing. Retrieved from https://books.google.iq/books?id=NxprDwAAQBAJ\&dq.

Yule, G. (1996). Pragmatics. UK: Oxford University Press.

Sample 8 (July 17, 2019)

\section{APPENDIX}

https://www.facebook.com/AIGInsurance/posts/2367076263551144

As a teenager, NatáliaSaltoratto was instantly captivated after her first brush with a Rubik's Cube at a New York toy store. Not one to shy away from a challenge, she immediately took to mastering the six-sided puzzle and its jumble of colorful squares. Her fascination with the cube led Natália to compete in professional speed-solving contests, eventually clocking in her fastest time at 21.18 seconds.

Those finely honed analytical skills complement Natália's role as an underwriter in Financial Lines in AIG's São Paulo, Brazil, office. "Unscrambling the cube is something that takes time and requires you to build new skills," she says. "That's what underwriting is. You don't graduate from college ready to become an underwriter."

A love of numbers and poring over balance sheets inspired Natália to switch careers from international tax law to underwriting two years ago, landing a job at AIG where she focuses on insurance for directors and officers.

"It's very dynamic," she says. "In my previous job, I can work for six months on one project for one client. Now, I'm usually reviewing multiple accounts. You have the financial analysis of the company. You take a look at their balance sheets, income statements and comments from the auditors so you can get a sense of the company."

Last year, Natália joined a diverse group of about 60 AIG underwriters in Dublin, Ireland, for a five-day Financial Lines University Technical Training program. "This is a company that invests in its employees and their learning," she says.

Back in São Paulo, Natália lives with her two Pomeranian dogs and is a Divemaster. Every few weeks, she dons a poofy skirt and heads off to Rockabilly dancing, a 1950s style of ballroom dancing similar to swing. But her cubes are never far, including a vast collection scattered at her desk. "I usually do the Megaminx," she says, referring to the 12-sided cousin of the original Rubik's version. "It's quieter." 